Al-Amwal, Volume 9, No. 1 Tahun 2017

\title{
Pengaruh Program Inklusi Keuangan BMT Al- Falah Terhadap Transaksi Rentenir
}

\author{
Finita Rahmadani, Nur Eka Setiowati
}

Program Studi Perbankan Syariah FSEI IAIN Syekh Nurjati Cirebon

E-mail : finitar13@gmail.com

\begin{abstract}
Abstrak
UMKM di Indonesia bermanfaat dalam hal pendistribusian pendatapan masyarakat. Tetapi modal menjadi kendalanya. BMT ini diharapkan dapat menjadi penyokong UMK (Usaha Mikro Kecil) yang tentu seusai dengan prinsip syariah dan menggantikan praktik rentenir yang dianggap mencekik para ekonomi kecil dalam jeratan hutang yang berkepanjangan. Dalam hal ini salah satu BMT yang sedang berkembang di Cirebon adalah BMT Al-Falah Cabang Sumber berdiri sejak tahun 1995. Berdasarkan pertanyaan yang diajukan adalah mengetahui pelaksanaan program Inklusi keuangan BMT Al-Falah pada pedagang Pasar Sumber. Mengetahui pengaruh Pengaruh program inklusi keuangan BMT Al-Falah terhadap praktik rentenir pada pedagan dan mengetahui strategi-strategi yang dilakukan BMT Al-Falah untuk mengurangi praktik rentenir pada pedagang di Pasar Sumber. Penelitian ini menggunakan pendekatan kuantitaif. Beberapa teknik pengumpulan data seperti observasi, wawancara, dokumentasi, dan penyebaran angket. Dalam penelitian ini diperoleh 20 orang anggota yang menjadi reponden. Hasil penelitian Pelaksanaan Program Inklusi Keuangan BMT Al-Falah pada pedagang di Pasar Sumber responden menyatakan Setuju sebanyak 52\%, dari data didapatkan sebanyak 500 pedagang yang tergabung dalam mitra BMT Al-Falah. Dan 44 pedagang yang mengakses pembiayaan pada BMT Al-Falah. Dari hasil teknik analisis data menggunakan Uji Korelasi Rank Spearman didapatkan bahwa data -0,426 data menyatakan hubungannya sedang, tanda (-) menyatakan bahwa Apabila Program Inklusi Keuangan BMT AlFalah meningkat maka Transaksi rentenir menurun.
\end{abstract}

Kata Kunci: Program Inklusi Keuangan Praktik Rentenir

\begin{abstract}
Small Medium Enterprises in Indonesia adavantage about distribution society income. But the problem is capital. BMT in this situation to hope to be a support of SMe (Small Business) which is certainly in accordance with the principles of shariahand to change Interest Transaction considers to worry for Micro Small Bussines in many debt.In this fact BMT who is to develop in Cirebon is Al-Falah's BMT Sumber of Branch Office built unti 1995 years later.Based the question of the problem is to know implementation Financial Inclusion Program Al-Falah's BMT on Seller in Sumber Market. To know the effect of Financial Inclusion Program Al-Falah's BMT Concern at Interest Transactionadan to know strartegy about Al-Falah's BMT do to reduce Interest Transaction on Seller in Sumber's Market. This research use quantitative method. Some Collection Techniques such as observation, documentation and questionnaire. In this research get 20 people who become respondent.The results of the research are Fisrt implementation
\end{abstract}


Financial Inclusion Program Al-Falah's BMT on Seller in Sumber Market states aggre as many as 52\%, based from data are 500 seller who is join in patner's Al-Falah BMT. From result analysis data technique use Test Correlation Rank Spearman that -0,426, the data of the correlation is medium. Sign negative it is mean if Financilan Inclusion Program Al-Falah's BMT Incrase, so Interest Transaction decline.

Keywords: Financial Inclusion Program, Interest Transaction

\section{Pendahuluan}

Pada era modern seperti ini kebutuhan masyarakat semakin meningkat namun peningkatan kebutuhan tidak diiringi oleh meningkatnya pendapatan. Dengan adanya masalah tersebut mendorong manusia melakukan sesuatu demi memenuhi kebutuhannya yang semakin lama semakin berkembang. Kebutuhan biasa yang dibutuhkan oleh masyarakat atau pengusaha adalah dana atau modal. Padahal, jika dilihat keberadaan UMKM di Indonesia sangat bermanfaat dalam hal pendistribusian pendapatan masyarakat.

Selain itu mampu menciptakan kreativitas, pada sisi lain UMKM, mampu menyerap tenaga kerja dalam skala besar sehingga dapat mengurangi jumlah pengangguran. Dapat diketahui bahwa keberadaan UMKM yang bersifat padat karya menggunakan teknologi yang sederhana dan mudah dipahami mampu menjadi wadah masyarakat untuk berkerja ${ }^{1}$. Namun ada kendala yang dimiliki UMKM yaitu dari segi modal dan pemasaran, dari hal ini munculah suatu model "Inklusi Keuangan".

Inklusi Keuangan merupakan upaya untuk mendorong sistem keuangan agar dapat diakses seluruh lapisan masyarakat, sehingga mendorong pertumbuhan ekonomi yang berkualitas sekaligus mengatasi kemiskinan ${ }^{2}$. Tetapi pemanfaatan model ini masih sangat sedikit di kalangan masyarakat Indonesia.

\footnotetext{
1 Anggraeni Dwi,F,dkk, "Pengembangan UMKM Melalui Fasilitas Pihak Eksternal dan Potensi Internal", Jurnal Administrasi 1, .no. $6: 1286$

${ }^{2}$ Irnawati Setyani, Delu Damelia, dkk, "Model Inklusi Keuangan Pada UMKM Berbasis Pedesaan”, Jurnal Ekonomi 6, no. 2 (2003) :153
}

Dalam Booklet Keuangan Inklusif (Bank Indonesia, 2014) menunjukkan hanya 49\% rumah tangga Indonesia yang memiliki akses terhadap lembaga keuangan formal. Sekitar $52 \%$ penduduk Indonesia hidup di daerah pedesaan dan sekitar $60 \%$ diantaranya tidak memiliki akses ke jasa keuangan formal.

Menurut World Pemanfaatan lembaga keuangan oleh masyarakat masih sangat minim, terutama untuk mengembangkan usahanya $^{3}$. Meskipun kemampuan bagi pengusaha menengah dalam hal modal masih bisa teratasi karena mereka masih bisa mendapatkan akses pembiayaan di bank, namun bagi para pelaku usaha kecil permodalan menjadi kendala yang besar karena mendapatkan akses pembiayaan di dunia perbankan relatif sulit untuk usaha kecil.

Hal ini terjadi karena bank syariah masih mensyaratkan adanya jaminan dalam pengajuan pembiayaan, karena itu tidak mungkin dipenuhi oleh para pelaku usaha kecil ${ }^{4}$. Lembaga sektor keuangan dalam permodalan sektor riil, yang sudah sejak lama hadir di indonesia dengan konsep perbankan, tetapi konsep perbankan teknis dilapangannya belum menyentuh Usaha Mikro Kecil (UMK) baik dari pedagang kaki lima sampai pedagang-pedagang yang berada di pasar

\footnotetext{
${ }^{3}$ Abdurahman Denizar, "LINKAGE PROGRAM BANK SYARIAH DENGAN BMT: Tinjauan Kritis Bagi

Pengembangan Sistem Keuangan Yang Lebih Kaffah”, Jurnal Ekonomi Syariah 2, no. 10 (Oktober 2015) $: 850$

${ }^{4}$ Ayogi Dwi, Kurnia Tuti, "Optimalisasi Peran BMT dalam Upaya Penghapusan Praktik Rentenir”,

Jurnal Syarikah 1, no. $1: 2$
} 
tradisional yang biasa disebut ekonomi rakyat kecil.

Tetapi jika para masyarakatnya dapat memanfaatkan jasa keuangan dengan mudah maka akan mendorong terjadinya peningkatan perputaran modal. Dengan begitu, lembaga keuangan dapat melaksanakanpemerataan modal di dalam masyarakat,yang kemudian akan mendorongpertumbuhan ekonomi. Namun, padakenyataannya saat ini Indonesia masihberada pada tahap inklusi keuanganyang belum mapan.

Karena masalah inilah munculnya kegiatan sektor keuangan mikro, yang kegiatannya berasal dari individu yang ada di masyarakat, kegiatan individu tersebut memberikan permodalan yang dibutuhkan UMK. Individu itu sering disebut rentenir, masyarakat kecil atau pengusaha kecil lebih mengandalkan jasa keuangan yang ditawarkan oleh rentenir karena lebih fleksibel dan cepat meskipun harus membayar bunga tinggi.

Rentenir dikatakan sebagai penompang keuangan masyarakat, akan tetapi keberadaannya itu sendiri tidak membawa kemaslahatan bagi masyarakat, tetapi terdapat masalah dalam bentuk kegiatan individu tersebut diantaranya adalah bentuk permodalan yang dilakukan oleh rentenir. Hutang piutang pada rentenir sangat diperlukan dengan kebutuhan para pedagang skala besar yang harus membeli barang dalam jangka waktu pendek.

Namun jika peminjam atau pedagang kecil dalam pembayaran kreditnya tidak sanggup untuk membayar maka jangka waktu pembayarannya akan diperpanjang, sehingga bunga akan semakin besar yang menambah beban si peminjam, bunga dan jangka waktu yang relatif pendeklah yang dijadikan sebagai ketentuan yang mengikat, namun hal tersebut dilarang dalam Islam.Sehingga praktek ini secara tidak langsung belum memberikan solusi dalam permasalahan ekonomi rakyat kecil dan mengandung unsur riba. Seperti yang kita ketahui riba itu dilarang bagi umat muslim, hal tersebut didasarkan Al-Qur'an Ar-rum ayat 39:

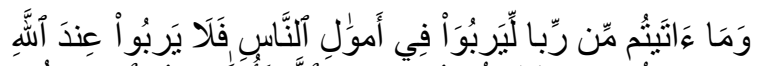

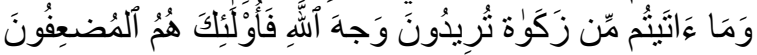
Arti: "Dan sesuatu riba (tambahan) yang kamu berikan agar dia bertambah pada harta manusia, maka riba itu tidak menambah pada sisi Allah. Dan apa yang kamu berikan berupa zakat yang kamu maksudkan untuk mencapai keridhaan Allah, maka (yang berbuat demikian) itulah orang-orang yang meilpatgandakan pahalanya."

Maksud ayat diatas adalah Allah Swt membenci perbuatan riba dan

perbuatan riba tersebut tidaklah mendapat pahala disisi Allah. Ayat ini berupa peringatan untuk tidak melakukan hal-hal negatif.

Al-Imron ayat 130:

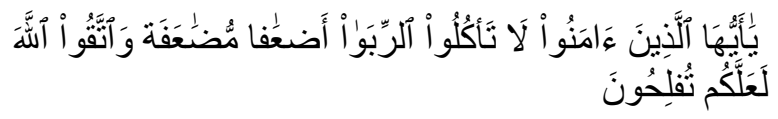

Arti: "Hai orang-orang yang beriman, janganlah kamu memakan riba dengan berlipat ganda dan bertakwalah kamu kepada allah supaya kamu mendapat keberuntungan".

Maksud ayat diatas pengharaman riba akan tetapi bentuk pengharaman pada ayat ini bersifat sebagian yaitu kepada kebiasaan orang saat itu yang mengambil riba dengan berlipat ganda dari modal.

Oleh karena itu dibutuhkannya lembaga keuangan mikro yang mempunyai kompetensi, yang bisa memenuhi kebutuhan masyarakat dan tidak menjerat mereka dalam lingkaran hutang yang berkepanjangan. Untuk itulah saat ini pemerintah (regulator), dalam hal ini OJK yang memiliki kewenangan pengaturan dan pengawasan di sektor jasa keuangan mulai concern pada penguatan lembaga keuangan sektor mikro, yang merupakan salah satu strategi menciptakan sistem keuangan yang lebih inklusif. 
Inklusi keuangan merupakan upaya untuk mendorong sistem keuangan agar dapat diakses seluruh lapisan masyarakat sehingga mendorong pertumbuhan ekonomi yang berkualitas sekaligus mengatasi kemiskinan. Inklusi Keuangan bertujuan untuk meniadakan segala bentuk hambatan terhadap akses masyarakat dalam memanfaatkan layanan jasa keuangan dengan didukung oleh infrastruktur yang ada.

BMT sesuai dengan upaya peningkatan sistem keuangan yang inklusif dan kegiatan yang dapat mengembangkan usaha-usaha produktif dan investasi dalam meningkatkan kualitas kegiatan ekonomi pengusaha bawah dan kecil antara lain mendorong kegiatan menabung dan menunjang pembiayaan kegiatan ekonominya ${ }^{5}$. Awal lahirnya BMT adalah "ekonomi berbasis masjid", kesadaran dari umat muslim bahwa fungsi masjid bukan hanya untuk ibadah semata, juga sebagai tempat jama'ah bersilaturahmi.

Berkumpulnya umat di masjid menjadi potensi strategis menjadikan fungsi masjid sebagai tempat pemberdayaan umat termasuk bidang ekonomi ${ }^{6}$. Dari situlah muncul gagasan pengembangan bisnis usaha kecil disekitar masjid dengan mendirikan pra koperasi Baitul Maal Tamwil atau BMT saja. Dalam Bahasa Indonesia sendiri istilah BMT sering disebut sebagai Balai Mandiri Terpadu. BMT merupakan lembaga ekonomi atau keuangan syariah non perbankan yang sifatnya informal, dikatakan informal karena lembaga ini didirikan oleh Kelompok Swadaya Masyarakat (KSM).

Kinerja Lembaga keuangan mikro (BMT) yang beroperasi atas dasar sistem syari'ah dimaksudkan agar memiliki kesempatan untuk menyediakan kebutuhan masyarakat miskin atau berpenghasilan rendah serta menggambarkan kemampuan LKM

\footnotetext{
${ }^{5}$ Soemitra Andri, M.A, Bank dan Lembaga Keuangan Syariah, (Jakarta: Kencana, 2012) ,452

${ }^{6}$ Aziz Abdul, M.Ag., Ulfah Mariyah, S.EI, Kapita Selekta Ekonomi Islam Kontemporer, (Bandung: Alfabeta, 2010),109
}

dalam menjadikan dirinya sebagai bank rakyat miskin yang sulit disentuh oleh lembaga keuangan formal (bank) yang selama ini berpihak kepada orang kaya daripada orang miskin $^{7}$.

Akhir tahun 1997 Indonesia mengalami krisis ekeonomi dan moneter, Peranan BMT cukup besar dalam membantu kalangan usaha kecil dan menengah, peran tersebut sangat penting dalam membangun kembali iklim usaha yang sehat di Indonesia. Ketika krisis ekonomi dan moneter, BMT sering melakukan observasi dan supervisi keberbagai lapisan masyarakat untuk menelaah terbukanya peluang kemitraan usaha.

Hal ini dilakukan untuk membangkitkan kembali sektor riil yang banyak dilakukan oleh usaha kecil dan menengah serta memperbaiki kesejahteraan ekonomi masyarakat secara keseluruhan. Karena itu BMT muncul sebagai penompang serta mencoba memberikan solusi bagi masyarakat ekonomi kecil yang ingin membangun usaha atau menambah modalnya dan supaya terhindar dari praktik rentenir dan lebih utama terhindar dari riba.

Sebenarnya muncul adanya krisis ekonomi tidak terlepas dari praktik-praktik atau aktivitas ekonomi yang dilakukan bertentangan dengan nilai keislaman seperti tindakan mengkonsumsi riba, monopoli, korupsi, tindakan malpraktek dan lainnya. Disini dengan memberikan solusi alternatif yaitu sistem ekonomi islam. Kegiatan bisnis BMT bertujuan membantu pengusaha kecil dengan memberikan pembiayaan dalam rangka mengembangkan usahanya.

Dengan kegiatan bisnis ini usaha berkembang dan BMT memperoleh pendapatan sehingga kegiatan BMT berkesinambungan secara mandiri. Dan program inklusi keuangan yang dijalankan oleh pemerintah yaitu OJK mendorong agar seluruh lapisan masyarakat dapat mengakses jasa keuangan, meningkatkan investasi dan

\footnotetext{
${ }^{7}$ Muhammad, Lembaga Keuangan Mikro Syariah, (Yogyakarta: Graha Ilmu, 2009), 84
} 
usaha, dan dapat mendapatkan hasil permodalan dari lembaga keuangan formal dan lembaga keuangan mikro. BMT ini diharapkan dapat menjadi penyongkong UMK (Usaha Mikro Kecil) yang tentu seusai dengan prinsip syariah sehingga BMT ini diharapkan dapat membantu Usaha mikro kecil, pedagang kecil dipasar dan menggantikan praktik rentenir yang dianggap mencekik para ekonomi kecil dalam jeratan hutang yang berkepanjangan.

Penelitian ini menggunakan metode deskriptif analitis, dengan pendekatan kuantitatif. Sampel yang digunakan sebanyak 20 pedagang. Teknik analisis data yang digunakan adalah korelasi rank spearman untuk mengetahui digunakan untuk mencari hubungan atau untuk menguji signifikasi hipotesis asosiatif bila masing-masing variabel dihubungkan berbentuk ordinal. Bahwa uji korelasi rank spearman merupakan bagian dari statistik non-parametik.

Penelitian ini bertujuan untuk mengetahui pelaksanaan program inklusi keuangan BMT Al-Falah terhadap Transaksi Rentenir, untuk mengetahui pengaruh program inklusi keuangan BMT Al-Falah terhadap Transaksi Rentenir, dan untuk mengetahuI strategi BMT Al-Falah dalam meminimalisir Transaksi Rentenir.

\section{Pembahasan}

\section{Definisi Umum Inklusi Keuangan}

Istilah sistem inklusi keuangan atau dalam bahasa inggris Financial Inclusion bersinonim dengan frasa inclusive financial system yang berarti sistem jasa layanan keuangan yang bersifat universal, nonekslusif. Inkulisivitas sistem keuangan ini sebenarnya lebih merujuk pada visi untuk menciptakan satu sistem jasa keuangan yang mampu menjangkau semua kalangan. Tidak hanya kalangan berada, tetapi juga kalangan berpangkat rendah atau miskin.

Dalam praktiknya, gagasan inklusi keuangan mengambil bentuk dalam skema yang kini lebih dikenal dengan microfinance. Inklusi Keuangan merupakan satu skema pembiayaan inklusif dengan tujuan utama memberikan berbagai layanan keuangan kepada kalangan miskin dan berpenghasilan rendah. Ragam layanan keuangan tersebut antara lain berupa kredit permodalan, tabungan, asuransi, serta layanan transfer keuangan. ${ }^{8}$

Inklusi keuangan merupakan upaya untuk mendorong sistem keuangan agar dapat diakses seluruh lapisan masyarakat sehingga mendorong pertumbuhan ekonomi yang berkualitas sekaligus mengatasi kemiskinan. Inklusi Keuangan bertujuan untuk meniadakan segala bentuk hambatan terhadap akses masyarakat dalam memanfaatkan layanan jasa keuangan dengan didukung oleh infrastruktur yang ada?

\section{Definisi Menurut Para Ahli}

Terdapat beberapa definisi yang menjelaskan batasan serta karakteristik utama Inklusi Keuangan:

1. Dalam Strategi Nasional Inklusi Keuangan adalah Hak setiap orang untuk memiliki akses dan layan penuh dari lembaga keuangan secara tetap, setiap orang untuk memiliki akses dan layanan penuh dari lembaga keuangan secara tepat waktu, nyaman, informatif, dan terjangkau biayanya, dengan penghormatan penuh kepada harkat dan martabatnya. Layanan keuangan tersedia bagi seluruh segmen masyarakat, dengan perhatian khusus kepada orang miskin, orang miskin produktif, pekerja migrant, dan penduduk di daerah terpencil ${ }^{10}$.

2. Merujuk definisi Perserikatan BangsaBangsa (PBB), terminologi Inklusi Keuangan mengacu kepada akses ke berbagai jasa keuangan, dengan biaya

\footnotetext{
${ }^{8}$ Nusron Wahid, Keuangan Inklusif Membongkar Hegemon Keuangan, (Jakarta: Gramdeia, 2014) ,54

${ }^{9}$ Setyani Irmawati, Delu Damelia, dan Dita Wahyu Puspita Model Inklusi Keuangan pada UMKM berbasis Pedesaan, Jurnal Ekonomi dan Politik (Universitas Negeri Semarang, 2013) :154

${ }^{10}$ Buku Saku Keuangan Inklusif. (Departemen Pengembangan Akses Keuangan dan UMKM Bank Indonesia, 2014):6
} 
yang wajar, bagi orang-orang yang dianggap tidak bankable serta mereka yang menjalankan usaha di pedesaan; misalnya pertanian atau pertenakan. Layanan-layanan tersebut mencakup tabungan, kredit jangka pendek, maupun jangka panjang, sewa guna usaha, hipotek, asuransi , pensiun, pembayaran, transfer uang untuk lingkup lokal maupun internasional.

3. Senada dengan PBB menurut Rajagan Commite mendefinisikan Inklusi Keuangan sebagai proses untuk memastikan bahwa kaum miskin dan/ atau kalangan berpenghasilan rendah mendapatkan layanan keuangan. Umumnya berupa kredit dengan jangka waku dan besaram biaya pengambilan masuk akal (reasonable).

4. Adapun definisi yang lebih operasional ditawarkan oleh House of Commons Treasury Committe yang menyebut bahwa Inklusi Keuangan merupakan kemampuan perorangan dalam mengakses berbagai produk jasa keuangan yang terjangkau serta sesuai dengan kebutuhannya.

5. A.Rahman mendefinisikan Inklusi Keuangan sebagai akses ke lembaga keuangan yang diselenggarakan secara resmi serta diatur dan diawasi oleh pemerintah. Definisi Rahman ini secara khusus mengacu ke dalam struktur kelembagaan financial inclusion di Bangladesh.

6. Menurut Otoritas Jasa Keuangan (OJK) Inklusi Keuangan (Financial Inclsuion) adalah segala upaya yang bertujuan untuk meniadakan segala bentuk hambatan yang bersifat harga maupun non-harga terhadap akses masyarakat dalam memanfaatkan layanan jasa keuangan sehingga dapat memberikan manfaat yang signifikan. Terhadap taraf hidup masyarakat wilayah dan kondisi geografis yang sulit dijangkau. ${ }^{11}$

Pada pokoknya skema Inklusi Keuangan ini menawarkan berbagai layanan keuangan ini menawarkan berbagai layanan keuangan yang bertujuan menjangkau semua segmen mayarakat dengan biaya yang terjangkau serta waktu pengembalian kredit yang masuk akal. Adapun aspirasi utama dari jalan pikiran Inklusi keuangan ialah mereduksi ketidakadilan ekonomi dengan cara menyediakan kesempatan yang sama ke dalam lembaga permodalan.

Jadi kesimpulan yang dapat ditarik bahwa inklusi keuangan baiknya dipahami sebagai dimensi utama dari jasa layanan keuangan. Yaitu akses atau kredit permodalan (acces to credit). Dalam hal ini akses kalangan miskin berpenghasilan rendah ke berbagai institusi keuangan, yang dimugkinkan dengan adanya skema penjaminan kredit oleh negara.

\section{Sejarah Inklusi Keuangan}

Gagasan Inklusi Keuanganbaru uncul sekitar 30-40 tahun belakangan.Meskipun demikian, sebagai ide dan praktik, microfinance yang merupakan fitur utama inklusi keuagan bukanlah hal baru. Skema kredit mikro dan tabungan yang bersifat informal sebenarnya sudah diperagakan selama berabad-abad. Di Eropa abad XV, gereja katolik pernah memiliki institusi pegadaian sebagai lembaga yang secara khusus disediakan untuk membantu kalangan menengah ke bawah.

Pada awal abad XVII, di Irlandia sudah terdapat lembaga pendanaan bagi kaum miskin. Pada sekitar 1840 tercatat kurang lebih ada 300 lembaga pendanaan bagi kaum miskin yang tersebar di seantero Irlandia. Memasuki abad XVII, lembaga-lembaga microfinance di Eropa semakin berkembang ke arah yang lebih

\footnotetext{
${ }^{11}$ Triani Fitriastuti, Dhina Mustika. S, Ike Purnamasari.

"Impelemntasi Keuangan Inklusif Bagi Masyarakat Perbatasan (Studi Kasua Pada Kutai Timur, Kabupaten Kertanegara dan Kota Samarinda, Kalimantan

Timur, Indonesia) Jurnal Ekonomi (Universitas Mulawarman, 2015) :1
} 
formal. Eksistensi lembaga keuangan skala kecil ini umunya diperuntukkan bagi kalangan masyarakat yang hidup di daerah pendesaan dan kaum miskin kota.

Dalam kurun waktu yang sama, di Jerman tumbuh semacam lembaga permodalan skala kecil yang mengusung tujuan memantu penduduk di pedesaan untuk membebaskan dirinya dari ketergantungan terhadap tengkulak (money landers). Memasuki abad XIX awal juga muncul perkembangan baru di Perancis dan Quebec. Secara umum, praktik microfinance di Eropa disebut-sebut berhasi menginsipirasi kemunculan praktik serupa di seanterp dunia.

Di kawasan Amerika Latin, misalnya, variasi praktik microfinance mulai bermunculan berkembang sejak 1990-an. Di kawasan ini, microfinance lebih banyak dimaksudkan untuk modernisasi sektor pertanian dan dimanfaatkan sebagai sarana untuk mereduksi hubungan ekonomi feodalistik yang opresif. Di kawasan Asia Tenggara, khususnya di Indonesia, praktik permodalan skala kecil sudah dilakukan sejak 1895, di bawah panji bendera Bank Pengkreditan Rakyat (BPR). ${ }^{12}$

Saat ini BPR memiliki sekitar 9000 cabang dan menjelma menjadi salah satu institusi keuangan microfinance terbesar didunia. Totalitas praktik yang terjadi di seantero dunia inilah yang merupakan cikal bakal lahirnya gagasan sistem inklusif keungan yang lebih mapan, maupun modern dan terintegritas dengan sektor institusi keuangan formal pada pertengahan era 1900-an. Memasuki abad XX, microfinance mulai dikelola tidak hanya oleh kalngan swasta tetapi juga oleh bank-bank negara.

Pada era ini antara 1950 hingga 1970-an, bank-bank pemerintah umumnya berfokus pada pemberian bantuan kepada petani, petani marginal dalam bentuk kredit pertanian skala

\footnotetext{
${ }^{12}$ Nusron Wahid, Keuangan Inklusif Membongkar Hegemon Keuangan,58
}

kecil. Namum skema bantuan pemerintah berupa subsidi tercata jarang sekali berhasil. Kegagalan tersebut umumnya disebabkan, dari sudut pandangn para petani misalnya karena subsidi dianggap sebagai hibah atau bantuan cuma-cuma. Sedangkan dari sisi pemerintah aliran subsidi seringkali tidak tepat sasaran. Akibatnya, tingkat pengembalian 'kredit' begitu rendah.

Hal ini membuat bank-bank pertanian tersebut sulit mempertahankan eksistensinya dan kemudian menghilang dari peredaran. Memasuki 1970-an, sektor microfinance mendapatkan kembali momentum kelahirannya. Hal ini terutama dipicu oleh perkembangan penting yang terjadi di Bangladesh dan Brazil. Kedua negara tersebut mempraktikan penyaluran kredit kepada kaum perempuan. Secara umum, pada periode ini berbagai inovasi microedit mulai kembali berhasil adalah inovasi yang dipraktikan Gramenen Bank.

Inovasi tersebut terutama berkaitan dengan tata cara baru mekanisme pengembalian kredit. Sistem pengembalian kredit baru ini dihabiskan pada solidaritas kelompok, di mana setiap anggota bertindak sebagai pihak penjamin bagi lainnya. Kesuksesan pendekatan sisterhood ini pun pada gilirannya tidak hanya berhasil membantu kalangan miskin dalam memperbaiki kondisi hidupnya, tetapi juga menjadi salah satu kunci kelangsungan dan perekembangan Gramenen Bank di Bangladesh.

Di kemudian hari, kesuksesan Gramenen Bank dengan satu dan lain cara

disebut-sebut menjadi satu tonggak yang mempercerah masa depan industri microfinance di seantero dunia. Kesuksesan di Bangladesh berhasil membuka mata dunia bawa orang-orang berpenghasilan rendah dan miskin ternyata bankable, dalam arti sanggup mengembalikan pinjamannya. Sejak itu, berbagai lembaga microfinance yang menerapkan metode sejenis bermunculan, 
antara lain di kawasan Amerika Latin, Amerika Serikat, dan India.

Di India, institusi keungan mikro sejenis bahkan dimiliki dan dikelola oleh serikat pekerja wanita. ${ }^{13}$ Secara umum, periode ini kerap disebut-sebut di dalam literatur sebagai kebangkitan kembali dunia microfinance. Memasuki era 1980-an, program-program microedit seluruh dunia mengalami kemajuan dan mulai menemukan kembali kebijaksanaan klasiknya yaitu membantu kaum miskin berpenghasilan rendah dalam usaha memperbaiki mutu kualitas hidupnya. Pada periode ini, institusi microfinance berhasil melihat dirinya sebagai sektor ekonomi yang memiliki prospek bisnis yang atraktir.

Penilaian itu didasarkan pada setidaknya dua hal. Pertama, pada fakta bahwa institusi microfinance sudah mampu melayani klien yang lebih luas. Kedua, karena institusi ini sudah bisa terus beroperasi dan melebarkan sayapnya tanpa harus merasa dibatasi oleh ketidakpastian subsidi dari pemerintah. Kepercayaan dan semangat inilah yang kelak menjadi dasar perkembangan lebih jauh institusi microfinance diseluruh dunia pada sepanjang era 1980-an. Era 1990-an adalah era dimana antusiasme terhadap institusi microfinance mengalami pertumbuhan yang signifikan. Pada periode ini aliansi serta networking internasional dalam memerangi kemiskinan. Singkat kata, era ini bisa disebut sebagai modern microfinance.

Di era ini institusi-institusi microfinance yang melayani berbagai kebutuhan usaha skala kecil semakin banyak bermunculan. Istilah microedit pun perlahan-lahan ditinggalkan dan digantikan dengan istilah yang lebih terdengan inklusif microfinance. Sasarannya sama, yaitu membantu kaum miskin kota dan mereka yang tertinggal di desa-desa, namun dengan berbagai adisi layanan keuangan lain yang mencakup tabungan (saving), asuransi (insurance), dan transfer keuangan (money

\footnotetext{
${ }^{13}$ Nusron Wahid, Keuangan Inklusif Membongkar Hegemon Keuangan,59
}

transfer).${ }^{14}$ Seiring dengan kemajuan ini, dilandasi semangat untuk lebih bisa menjangkau klien-klie miskin yang lebih luas, institusi microfinance perlahan-lahan bertransformasi menjadi lembaga-lembaga yang bersifat lebih komersial.

Karakter komersial ini ditandai dengan makin lengkapnya fitur-fitur laynan keuangan plus penekana pada penguatan kapasitas institusional yang dibutuhkan untuk perkembangan institusi keuanga itu sendiri. Elemen-elemen kunci inilah yang terus berkembang sepanjang 1990-an hingga awal 2000-an. Dalam kurun waktu tiga puluh tahun terhitung sejak 1970-an, dipicu oleh keberhasilan inovasi Gramenen Bank, skema inklusi keuanga, skema yang mencoba memasukan kembali pihak-pihak yang selama ini diekslusi dari institusi jasa keuangan mencapai kemajuan yang sangat berarti.

Dalam periode itu, dunia menyaksikan bahwa kaum miskin berpenghasilan rendah adalah kalangan-kalangan yang giat, tekun, dan penuh semangat. Dunia mulai menyadari bahwa kalangan miskin pada dasarnya merupakan bagian integral dari industri keuangan. Kemajuan ini pada gilirannya berhasil memicu penguatan lebih jauh dari industri microfinance di seluruh dunia. Hal ini tentu saja berdampak pada makin tebalnya kepercayaan pada daya kerjadi dari jalan pikiran inklusi keuangan itu sendiri. Namun dengan catatan kemajuan yang mengagumkan seperti itu pun, jalan ke arah pengentasan kemiskinan terlihat masih panjang dan berat. Kenyataan ini, dalam perspektif sistem menerus memperluas akses bagi setiap pihak yang membutuhkan jasa layanan keuangan.

\section{Tujuan Inklusi Keuangan}

Dilihat dari segi intensinya, skema jasa keuangan inklusif dimaksudkanuntuk mengatasi situasi kemiskinan. Yang pertama ditempuh ialah membuka eksklusivitas syarat pemberian modal yang umumnya dipraktikan

\footnotetext{
${ }^{14}$ Nusron Wahid, Keuangan Inklusif Membongkar Hegemon Keuangan, 60
} 
oleh lembaga keuangan. Pada umunya lembaga keuangan hanya bersedia memberikan layanan permodalan kepada pihak-pihak yang dianggap bankable ${ }^{15}$. Hal ini wajar sejauh kita memperhatikan krusialnya prinsip kehatihatian (prudentiality) bagi kelangsungan suatu lembaga keuangan.

Prinsip prudensialitas ini pada dasarnya merupakan prinsip yang baik, terutama jika kita berbicara di ranah pertukaran ekonomi. Namun bukan berarti prinsip ini tidak menjadi satu-satunya parameter penentu layak tidaknya kalangan berpenghasilan rendah atau miskin mendapatkan asistenisasi permodalan. Faktanya dibawah naungan prinisip prudensialitas yang keras ini, kalangan berpenghasilan rendah dan miskin selalu dianggap tidak memenuhi syarat kelayakan sebagai penerima kredit.

Pada akhirnya mereka harus tereksekusi atau tercoret sebagai pihak yang tidak patut mendapatkan asistensi permodalan. Padahal, secara sosial-ekonomi justru pihak-pihak inilah yang sebenarnya paling memerlukan bantuan permodalan. Baik untuk keperluan meningkat financial security, memanfaatkan peluangpeluang usaha, maupun dalam rangka mengembangkan usahanya. Dengan demikian pertama-tama istilah Inklusi Keuangan, lebih tepat diawali sebagai suatu usaha untuk menggeser paradigma lama yang telah mendarah daging di institusi permodalan, yang umumnya mengeksklusi kalangan nonbankable dari haknya untuk mendapatkan bantuan permodalan.

Kedua, didalam gagasan Inklusi Keuangan ini terdapat satu niat, yaitu kesediaan untuk kembali memasukan pihak yang selama ini dieksklusi atau disingkirkan dari institusi keuangan sebagai pihak yang layak mendapatkan berbagai layanan.

\section{Manfaat Inklusi Keuangan}

Ada beberapa manfaat yang bisa diperoleh dari sistem layanan keuangan inklusif.

\footnotetext{
${ }^{15}$ Nusron Wahid, Keuangan Inklusif Membongkar Hegemon Keuangan ,64
}

Pertama, soal akses. Akses ke dalam kreidt permodalan secara otomatis akan membuka peluang usaha dan/ atau bisa dimanfaatkan untuk meningkatkan besaran investasi para pengusaha kecil. Kedua, terbukanya jaringan ke dalam sektor keuangan formal memungkinkan kalangan miskin bisa mengakses bermacam jeniskredit usaha, memanfaatkan berbagai opsi tabungan, plus memanfaatkan berbagai produk asuransi dengan persyaratan lunak.

Ketiga, dalam hal biaya kemudahan mengakses modal usaha ke sektor keuangan formal akan mengurangi pertumbuhan kredit ke sektor infomal yang biasanya dijalankan oleh para tengkulak yang umumnya mematok biaya pengembalian kredit yang tidak masuk akal.Tersedianya ke dalam lembaga keuangan formal ditaksir akan sanggup mereduksi biayabiaya pengembalian kredit yang harus ditanggung oleh kalangan miskin berpenghasilan rendah. ${ }^{16}$

Keempat, berbagai rekening yang sudah teregistrasi di institusi keuangan formal pada gilirannya bisa digunakan untuk berbagai keperluan yang sangat penting, misalnya untuk memperoleh berbagai manfaat dari programprogram pemerintah seperti listik, air bersih dan sebagainya. Selain itu berbagai studi menunjukan bahwa akses ke dalam jasa keuangan memungkinkan kaum miskin menyimpan uang secara aman diluar rumahnya.

Ini dapat mencegah terkonsentrasinya kekuatan ekonomi segelintir orang. Akses ke dalam jasa layanan keuangan terbukti menjdi mitigasi risiko yang ampuh bagi kaum miskin, terutama saat mereka berhadapan dengan dampak kirisi ekonomi atau bencana alam.

\section{Visi Inklusi Keuangan}

Menjadikan strategi Inklusi Keuangan sebagai bagian dari strategi besarpembangunan ekonomi, penanggulangan kemiskinan, pemerataan pendapatan dan stabilitas sistem

\footnotetext{
${ }^{16}$ Nusron Wahid, Keuangan Inklusif Membongkar Hegemon Keuangan ,65
} 
keuangan. Inklusi Keuangan adalah strategi untuk mencapai tujuan pembangunan ekonomi yang lebih luas, yaitu penanggulangan kemiskinan dan peningkatan kesejahteraan masyarakat, serta bagian dari strategi untuk mencapai stabilitas sistem keuangan.

Kelompok miskin dan marjinal merupakan kelompok yang memiliki keterbatasan akses ke layanan keuangan. Tujuan Inklusi Keuangan adalah memberikan akses ke jasa keuangan yang lebih luas bagi setiap penduduk, namun terdapat kebutuhan untuk memberikan fokus lebihbesar kepada penduduk miskinMenyediakan jasa dan produk keuangan yang sesuai dengan kebutuhan masyarakat. Konsep Inklusi Keuangan harus dapat memenuhi semua kebutuhan yang berbeda dari segmen penduduk yang berbeda melalui serangkaian layanan holistik yang menyeluruh.

Meningkatkan pengetahuan masyarakat mengenai layanan keuangan. Hambatan utama dalam Inklusi Keuangan adalah tingkat pengetahuan keuangan yang rendah. Pengetahuan ini penting agar masyarakat merasa lebih aman berinteraksi dengan lembaga keuangan.Meningkatkan akses masyarakat ke layanan keuangan. Hambatan bagi orang miskin untuk mengakses layanan keuangan umumnya berupa masalah geografis dan kendala administrasi. Menyelesaikan permasalahan tersebut akan menjadi terobosan mendasar dalam menyederhanakan akses ke jasa keuangan $^{17}$.

\section{Rentenir \\ Definisi Umum}

Rentenir berasal dari kata rente, yang berarti bunga. Dalam Kamus Besar Bahasa Indonesia, rentenir berarti orang yang mencari nafkah denganmembungakanuang; tukang riba; pelepas uang; lintah darat. Rentenir merupakan suatu jenis pekerjaan yang sesungguhnya tidak jauhberbeda dengan bank dan lembaga keuangan non bank yang

\footnotetext{
${ }^{17}$ Buku Saku Inklusif Keuangan(Departemen Pengembangan
} Akses Keuangan dan UMKM Bank Indonesia) :7 bergerak dibidangjasa pelayanan simpan pinjam uang. Perbedaannya, rentenir adalah wiraswastayang tidak berbadan hukum, yang mengelola usahanya sendiri dengankebijakan dan peraturan sendiri.

Rentenir adalah orang yang menawarkan pinjaman jangka pendek tanpa jaminan dan juga disebut lintah darat karena menarik bunga yang tinggi pada setiap paket kredit. Sebagian besar rentenir beropersi dipasar-pasar pedesaan dan mereka juga sering mengunjungi orang dari pintu kepintu ${ }^{18}$. Sumber dana yang dimiliki rentenir dalam melaksanakan usahanyaberasal dari modal sendiri, disamping itu juga dari pinjaman orang lain dikota dengan tingkat suku bunga yang cukup tinggi.

Rentenir memberikan kredit untuk pertanian, perdagangan, kerajinan dan juga pereluankonsumsi ${ }^{19}$. Dalam Islam, praktik rentenir adalah sama dengan istilah mu'amalat ribawiyah yaitu tambaham terhadap modal uang yang timbul akibat suatu transaksi utangpiutang yang harus diberikan oleh peminjam kepada pemilik uang pada saat hutang jatuh tempo.

Praktik rentenir, secara hukum positif, dilarang Indonesia karenabeberapa alasan berikut:

a) Adanya larangan melakukan usaha pelepasan uang, sebagaimana yangdisebutkan dalam Pasal 1 UndangUndang Pelepas Uang atau Geldscheiter Ordanantie dan sesuai dengan ketentuan Pasal II Aturan Peralihan UUD1945;

b) Batal demi hukum karena tidak memenuhi syarat sahnya perjanjian yangdiatur dalam pasal 1320 Burgerlijk Wetboek, yaitu, sesuatu yang halal atautidak melanggar peraturan perundang-undangan;

c) Rentenir atau lintah darat dianggap sebagai salah satu bentuk penyakitmasyarakat, sehingga harus

\footnotetext{
${ }^{18}$ Heru Nugraha. Uang, Rentenir dan Hutang Piutang di Jawa, (Yogyakarta: Pustaka Pelajar, 2001),80

${ }^{19}$ Raried Wijaya, Perkreditan Bank dan Lembaga-Lembaga Keuangan, (Yogyakarta: BPFE, 1991),208.
} 
dicegah dan ditanggulangi sebagaimanatersebut dalam Pasal 13, Pasal 14 dan Pasal 15 ayat (1c) UndangUndangNomor 2 Tahun 2002 tentang Kepolisian Negara Republik Indonesia.Karena praktik rentenir dinilai sebagi salah satu aktivitas yang dilarangdi Indonesia berdasarkan peraturan atau hukum positif yang berlaku, makapara pelaku praktik ini; baik pemberi pinjaman dan peminjam, dapatdikenakan sanksi hukum.

\section{Definisi Menurut Para Ahli}

a. Menurut Dale. W. Adam Rentenir adalah individu yang memberikan jangka pendek, tidak menggunakan jaminan yang pasti, bunga relatif tinggi dan selalu berupaya melanggengkan kredit dengan nasabahnya ${ }^{20}$.

b. Heru Nugroho menyebutkan bahwa rentenir adalah sosok sumber daya yang sangat diperlukan bagi para pedagang untuk mendukung aktivitasnya baik secara langsung ataupun tidak langsung. Secara langsung, pinjaman dari rentenir digunakan untuk kegiatan produksi, secara tidak langsung dapat digunakan untuk kebutuhan konsumsi baik secara wajar ataupun konsumtif.

\section{Sejarah Perkembangan Rentenir di Indonesia}

Tidak ada data yang pasti sejak kapan lembaga informal ini ada diIndonesia, yang jelas lembaga informal ini tumbuh subur berdampingandengan lembaga formal $^{21}$.Literatur sejarah menjelaskan bahwa maraknya praktik rentenir inipada masa penjajahan koloniel melalui tangan-tangan pribumi walaupunsebelumnya juga sudah ada pada masa kerajaan pribumi. Pendirianlembaga-lembaga keuangan bank pada masa kolonial pun dilakukansebagai

\footnotetext{
${ }^{20}$ Khudzaifah Dimyanti, Tesis Profil Pelepas Praktek Uang Rentenir, (Universitas Diponogor, 1997), 16

${ }^{21}$ Rarried Wijaya, Perkreditan Bank dan Lembaga-Lembaga Keuangan ,208-209
}

antisipasi bagi praktik rentenir. Dengan dikeluarkannya pakto(paket Oktober) No. 27 tahun 1988 menandahkan bahwa praktik rentenirsudah menjadi masalah bagi pembangunan Indonesia sebelumnya.

Sehingga akhirnya pemerintah mengambil kebijakan dengan pendirian BPR di daerahdaerah pedesaan. Dari pengadopsian sistemsistem kolonial tersebut perkembanganrentenir ada sampai sekarang. Para pemburu renten pergi menawarkanjasanya kepada penduduk yang memerlukan uang baik untuk kebutuhankonsumsi maupun produksi mereka. Perkembangan rentenir yangmenawarkan jasa kredit kepada masyarakat mikro dilakukan denganmendatangi individu dari rumah ke rumah, tidak hanya dalam bentukmenjajahkan jasa kredit uang tetapi juga dengan modus pedagang kelilingbarang-barang kebutuhan masyarakat dan embayarannya pun bolehdicicil.

\section{Rentenir dilihat dari segi ekonomi Islam.}

Bila ditinjau dari segi fiqih, menurut Qardhawi bunga bank samadengan riba yang hukumnya jelas-jelas haram. Suatu sistem ekonomiIslam harus bebas dari bunga (riba). Hanya sistem ekonomi islam yangdapat menggunakan modal dengan benar dan baik, karena dalam sistemekonomi kapitalis dijumpai bahwa manfaat keuntungan teknik yang dicapai oleh ilmu pengetahuan hanya bisa dinikmati oleh segelintir orang saja. ${ }^{22}$ Begitu banyak malapetaka yang melanda umat manusia masa kini, khususnya dalam bidang ekonomi.

Dengan bentuknya yang sangat keji yang belum pernah terjadi di jaman jahiliyah, ialah bahwa para pelaku riba atau rentenir di jaman lampau hanya dilakukan secara individual dirumah sendiri, kini dengan mengatasnamakan lembaga, yayasan, dan bank-bank moderen. Mereka mampu memliki kekuatan dan kekuasaan yang begitu hebat.

\footnotetext{
${ }^{22}$ Vetihzal Rivai dan Arviyan Arifin. Islamic Banking. (Jakarta: Bumi Aksara, 2010) ,318
} 
Sanggup berperan dan ikut campur dalam lembaga=lembaga pemerintahan.

Dengan segala fasilitas yang mereka miliki mampu menumbuhkan dan membentuk pendapat umum di kalangan masyarakat awam dan miskin, yang daging dan tulang mereka telah dimakan oleh pelaku riba atau rente dalam naungan sistem ekonomi riba. Menurut Imam Ar-Razi praktik riba (bunga) dalam ekonomi islam sangatlah dilarang dalam hukum Islam (Fatwa MUI No. 1 tahun 004 tentang bunga), karena membuat bencana yang merusak, merampas kekayaan orang lain, merusak moralitas, melahirkan benih kebencian dan permusuhan dan yang kaya semakin kaya, yang miskin semakin miskin.

Terkecuali menurut para ekonomi kapitalis yang menganggap bahwa bunga (riba) adalah tempat berputarnya sistem perbankkan dan tanpa bunga maka ibarat hidup tanpa nyawa dan seluruh ekonomi akan lumpuh.Lain halnya dengan ekonomi Islam, praktik riba sangat menjauhkan manusia dari rahmat Allah diatas akhlaknya, agama, kesejahteraan danperekonomian masyarakat. Malahan Allah akan mengadzab orang yang berbuat riba (rentenir) karena sesuatu yang ia lakukan sangatlah merugikan dan memberiakan mafsadat bagi orang lain khususnya yang menjadi korban praktik rentenir.

Dalam ekonomi Islam sudah berulang kali dijelaskan, praktik rente (riba) adalah keuntungan dari berbagai pinjaman yang diharamkan. Didalam syara' telah dijelaskan bahwa yang telah melarang riba dengan larangan yang tegas, berapapun jumlahnya, baik sedikit maupun banyak. Harta hasil riba hukumnya jelas-jelas haram.

\section{Baitul Maal Wal-Tamwil (BMT) Definisi Baitul Maal Wal-Tamwil}

Baitul Maal Wal-Tamwil merupakan salah satu lembaga ekonomi dan keuangan yang dikenal luas pada masa-masa awal. Baitul al Maal berkembang pada masa kejayaan islam berfungs sebagai institusi keuangan publik, yang oleh sebagian pengamat ekonomi disesjajarkan dengan lembaga yang menjalankan fungsi perekonomian modern, bank sentral ${ }^{23}$. Baitul maal (BM) setelah berubah menjadi Baitul Maal wal-tamwil adalah lembaga keuangan mikro yang dioperasikan dengan prinsip bagi hasil (profit sharing), menumbuhkembangkan bisnis usaha mirko dan kecil dalam rangka mengangkat derajat dan martabat serta membela kepentingan kaum fakir miskin ${ }^{24}$. Baitul maal wal tamwil (BMT) merupakan suatu lembaga yang terdiri dari dua istilah yaitu Baitul Maal dan baitul tamwil.

Baitul maal lebih mengarah pada usahausaha pengumpulan dan penyaluran dana yang nonprofit seperti: zakat,infaq, dan sedekah. Adapun baitul tamwil sebagai usaha pengumpulan dan penyaluran dana komersial. Usaha-usaha tersebut menjadi bagian yang tidak terpisahkan dari BMT sebagai lembaga pendukung kegiatan ekonomi masyarakat kecil dengan berlandaskan islam Menurut para ahli:

a. Arief Budiharjo Baitul Maal wal Tamwil (BMT) adalah kelompok swadaya masyarakat yang berupaya mengembangkan usaha-usaha produktif dan investasi dengan sistem bagi hasil untuk meningkatkan ekonomi pengusaha kecil-bawah dalam pengentasan kemiskinan.

b. Amin Azis bahwa BMT adalah balai usaha mandiri terpadu yang dikembangkan dari konsep Baitul Maal wal Tamwil. Dari segi baitulmal, Baitul maal wal tamwil menerima titipan Bazis dari dana zakat dan sedekah memanfaatkannnya untuk kesejahteraan masyarakat kecil, fakir, miskin. Pada aspek baitul maal wal tamwil-BMT mengembangkan usaha-usaha produktif

\footnotetext{
${ }^{23}$ Muhamad. Lembaga Ekonimi Syariah. (Yogyakarta: Graha Ilmu, 2007), ,55

${ }^{24}$ Nurul Huda dan Mohamad Heykal. Lembaga Keuangan Islam Tinjauan Teoritis dan Praktis, (Jakarta: Kencana Prenada Media Group, 2010) .363
} 
untuk meningkatkan pendapatan kecil dan anggota ${ }^{25}$.

c. Menurut Dzajuli BMT adalah lembaga keuangan terpadu yang isinya berintikan konsep Bayt al-mal wa al-tamwil dengan kegiatan mengembangkan usaha-usaha produktif dan investasi dalam meningkatkan kualitas kegiatan ekonomi pengusaha kecil dengan antara lain mendorong kegiatan menabung dan menunjang pembiayaan kegiatan ekonominya ${ }^{26}$.

Jadi berdasarkan pengertian diatas Baitul Maal wal Tamwil adalah lembaga keuangan syariah atas dasar swadaya masyarakat yang mengarah kepada kelompok ekonomi masyarakat kecil, berupaya untuk mengembangkan usaha-usaha produktif dan investasi dengan sistem bagi hasil, serta penyaluran dana nonprofit seperti Bazis dengan tujuan meingkatkan ekonomi usaha kecil dan pengentasan kemiskinan

Sejarah Perkembangan BMT di Indonesia

Latar belakang berdirinya BMT bersamaan dengan usaha pendirian bank syariah di Indonesia, yakni tepatnya pada tahun 1990-an. BMT semakin berkembang tatkala pemerintah mengeluarkan kebijakan hukum ekonomi UU No.7 Tahun 1992 tentang perbankan dan PP No. 72/1992 tentang Bank Pengkreditan Rakyat berdasarkan bagi hasil. Pada saat bersamaan, Ikatan Cendikiawan Muslim Indonesia (ICMI) sangat aktif melakukan pengakajian intensif tentang pengembangan ekonomi islam di Indonesia.

Dari berbagai penelitian dan pengkajian, maka terbentuklah BMT di Indonesia. ICMI berperan dalam mendorong pendirian BMT di Indonesia. Di samping ICMI, beberapa organisasi massa Islam seperti Nahdatul Ulama (NU) , Muhammadiyah, Persatuan Islam

\footnotetext{
${ }^{25}$ H.Abdul Manan, Hukum Ekonomi Syariah dalam Perspektif Kewenangan dan

Peradilan Agama. (Jakarta: Kencana Prenanda Media Group, 2012),345

${ }^{26}$ Muhamad. Lembaga Ekonomi Syariah ,59
}

(Persis) dan ormas-ormasi Islam lainnya mendukung upaya pengembangan BMT di seluruh Indoensia.

Hal tersebut dilakukan untuk membangun sistem ekonomi islam melalui pendirian lembaga keuangan syari'ah. Hasil positif mulai dirasakan oleh masyarakat terutama kalangan usaha kecil dan menengah. Mereka banyak memanfaatkan pelayanan BMT yang kini tersebar luas di seluruh Indonesia. Hal ini disebabkan mereka memperoleh banyak keuntngan dan kemudahan dari BMT yang tidak mereka peroleh sebelumnya dari lembaga sejenis yang menggunakan pendekatan konvensional.

Baitul Maal Wa Tamwil (BMT) merupakan balai usaha mandiri terpadu yang isinya berintikan lembaga bait al-mal wa al-tamwil, yakni merupakan lembaga usaha masyarakat yang mengembangkan aspek-aspek produksi dan investasi untuk meningkatkan kualitas kegiatan ekonomi dalam skala kecil dan menengah. Dalam diskursus ekonomi islam. BMT semakin populer, setelah dipicu oleh kesadaran masyarakat muslim tanah air untuk mencari model ekonomi alternatif yang mampu mendukung perkembangan sektor usaha kecil dan mikro. ${ }^{27}$

Kebutuhan masyarakat akan lembaga keuangan dan perbankan yang menggunakan sistem syariah sesungguhnya sangatlah wajar, mengingat sebagai besar masyarakat Indoensia beragamakan muslim. BMT masuk dalam kategori koperasi syari'ah yakni lembaga ekonomi yang berfungsi untuk menarik, mengelola dan menyalurkan dana dan, oleh dan untuk menarik, mengelola dan menyalurkan dana dari, oleh dan untuk masyarakat. Jika demikian, berarti BMT dapat disebut sebagai lembaga swadaya ekonomi umat yang dibentuk dan, oleh dan untuk masyarakat.

\footnotetext{
${ }^{27}$ Mulyaningrum, Baitul Maal Wal Tamwil Peluang Dan Tantangan Dalam Pengembangan Lembaga Keuangan Mikro. (Bakrie Scool Of Management,2009):6
} 
Fungsi, Tujuan, Visi, Misi dan Pengelolaan Usaha BMT

Secara Konseptual, BMT memiliki dua fungsi ${ }^{28}$ :

a. Baitulmal (Bait: Rumah, Maal: Harta) menerima titipan dana ZIS (Zakat Infaq, dan sedekah) serta mengoptimalkan distribusinya dengan memberikan santunan kepada yang berhak (para asnaf) sesuai dengan peraturan dan amanah yang diterima.

b. Baitut Tamwil (Bait: Rumah at-tamwil: pengembangan harta melakukan kegiatan pengembangan usaha produktif dan investasi dalam meningkatkan kualitas ekonomi pengusaha mikro dan makro terutama mendorong kegiatan menabung dan menunjang pembiayaan ekonominya.

BMT bertujuan mewujudukan kehidupan keluarga dan masyarakat di sekitar BMT yang selamat, damai dan sejahtera. Selain fungsi dan tujuan BMT juga memiliki visi dan misi. Visi BMT dalah mewujudkan kualitas masyarakat disekitar BMT yang selamat, damai dan sejahtera dengan mengmbangkan lembaga usaha dan BMT dan POKUSMA (Kelompok Usaha Muamalaah) yang maju berkembang, terpercaya, aman, nyaman, transparan, dan berkehati-hatian.

Misi BMT adalah mengembangkan POKUSMA dan BMT yang maju berkembang, terpercaya, aman, transparan, dan berkehatihatian sehingga terwujud kulaitas masyarakat di sekita BMT yang selamat, damai, dan sejahtera. Untuk mencapai visi dan pelaksanaan misi dan tujuan BMT, maka BMT melakukan beberapa usaha:

1) Mengembangkan kegiatan simpan pinjam dengan prinisp bagi hasil/syari'ah.

2) Mengembangkan lembaga dan bisnis kelompok usaha muamaalah yaitu

\footnotetext{
${ }^{28}$ Nurul Huda dan Acham Aliyadin, Keuangan Publik Islam Pendekatan Teoritis dan Sejarah, (Jakarta:

Kencana Prenada media Group, 2012) ,285
}

kelompok simpan pinjam yang khas binaan BMT.

3) Jika BMT telah berkembang cukup mapan, memprkasai pengembangan badan usaha sektor riil, busril dari pokusma-pokusa sebagai badan usaha pendamping.

\section{Penelitian Terdahulu}

Penelitian dari Jajang Nurjaman (2010)

Peranan BMT Al-Fath IKMI ciputat dalam mengatasi dampak negatif praktek rentenir mengenai prakteknya sudah berjalan dengan baik melihat dari banyak mitra-mitra usaha yang meninggalkan rentenir dan banyak berpindah untuk bergabung menjadi mitra BMT. Adapun perban BMT Al-Fath IKMI ciputat yang sudah berjalan:

- Memberikan edukasi pendidikan kepada masyarakat dan diajak berpikir lebih baik untuk keberlangsungan usahanya

- Diajak mitra untuk bergabung dengan BMT Al-fat IKMI

- Sosialisasi kepada masyarakat seperti: mengadakan kegiatan-kegiatan sosial seperti,penyebaran brosur-brosur

- Pola pelayanan jemput bola untuk menabung

BMT berpotensi besar mengurangi angka kemiskinan di Indonesia karena BMT bergerak di sektor mikroekonomi yang rata-rata tidak terjangkau oleh perbankan islam pada umumnya. Kesulitan akses masyarakat yang menjalankan usaha mikro kepada sumber modal yang menjadi sebab banyaknya masyarakat yang terjerat pada rentenir. Jika rentenir dapat dihapus atau dibatasi geraknya dengan sendirinya BMT akan lebih mudah dikembangkan.

Penelitian dari Arief Setiawan (2012)dalam penelitiannya mengkaji tentang peran BMT dalam meningkatkan kinerja mitra binaannya yaitu berupa pembiayaan permodalan maupun pembinaan usaha, mitra binaan disini bisa berupa petani bawang,pedagang, meubel,bengkel dll. Melalui program pembiayaan permodalan maupun 
pembinaan usaha menjadikan motivasi bagi mitra binaan untuk meningkatkan kinerjanya. Peran BMT Al-ikhlas dalam menyelesaikan masalah yang paling sering dihadapi pengusaha kecil maupun besar, yaitu modal. Dengan sistem bagi hasil para nasabah atau pengusaha dapat meningkatkan modal usahaya tanpa diberatkan adanya bunga. Dengan produk pembiayaan inilah pengusaha menjadikan sebagai peluang mengembangkan usaha dengan meningkatkan kinerja, karena tidak tercekik dengan hutang dan bunga yang tinggi, banyak pengusaha yang mengeluh karena tingginya bunga meminjam kepada rentenir.

Penelitian dari Rozalinda (2013)dalam penelitian ini di pasar-pasar tradisonal Padang pada umunya pedangang meminjam kepada rentenir. Transaksi yang dinamakan julo-julo tembak (perputaran uang antara ketua atau kepala dengan masyarakat yang membutuhkan dana cepat dengan cara menerima dulu uang kemudian mencicil waktunya.) ini sudah lama ada sebelum hadirnya BMT. Peran BMT dalam membebaskan dari rentenir ini adalah Sosialisasi tentang ekonomi syariah yang dilakukan pihak BMT kepada masyarakat dan perannya dalam membebaskan masyarakat dari rentenir. BMT belum berperan secara signifikan dalam membebaskan masyarakat dari belenggu rentenir. Belum maksimalnya upaya BMT yang dilakukan dalam membebaskan masyarakat dari praktik rentenir yang cenderung lebih proaktif dalam menawarkan jasa mereka ke pedagang.

Penelitian dari Deni Insan Kamil (2015) Pengaruh Rentenir Terhadap Kesejahteraan Pedagang Pasar Tradisional Studi Pasar Legi Bugisan Jogjakarta. Dalam penelitian ini menunjukan bahwa di Pasar Legi Yogyakarta memiliki pengaruh terhadap kondisi kesejahteraan pedagang pasar. Partisipasi rentenir dengan peminjaman uang berfungsi untuk menutup segala kekurangan kebutuhan para pedagang. Bisa dikatakan bahwa meskipun rentenir memberikan bunga tinggi, akan tetapi mereka sedikit lebih membantu untuk mencukupi kondisi keuangan tersebut. Adanya uang sebagai alat pembayaran bisa dijadikan sebagai suatu hal yang dapat mengubah kondisi kesejahteraan mereka.

\section{Metode Penelitian}

Instrumen penelitian ini terdiri dari 15 pertanyaan dimana variabel $\mathrm{x}$ ada 10 item pertanyaan dan variabel y ada 5 pertanyaan dengan interval jawaban diberi skor 1 (satu) dan yang tertinggi 5 (lima). Dalam uji instrumen dan analisis data pada penelitian ini, peneliti menggunakan program komputer khusus untuk analisis data statistik yaitu program SPSS, di mana penelii menggunakan SPSS versi 20.0.

\section{Teknik Analisis Data}

Tujuan dari teknik analisis data untuk mengetahui apakan program Inklusi Keuangan BMT Al-Falah (X) mempunyai pengaruh positif terhadap Transaksi rentenir(Y) pada pedagang di Pasar Sumber.

\section{Hasil Penelitian}

Berdasarkan hasil penelitian dapat diketahui bahwa pelaksanaan program inklusi keuangan BMT Al-Falah pada pedagang di Pasar Sumber, bahwa jawaban respoden mengenai pelaksanaan program inklusi keuangan BMT Al-Falah mengatakan setuju sebanyak $52 \%$. Dan sangat setuju $42,5 \%$, raguragu $3,5 \%$ dan tidak setuju 2\%. Telah diperoleh data seberapa banyak para pedagang yang telah mengakses pada BMT Al-Falah.

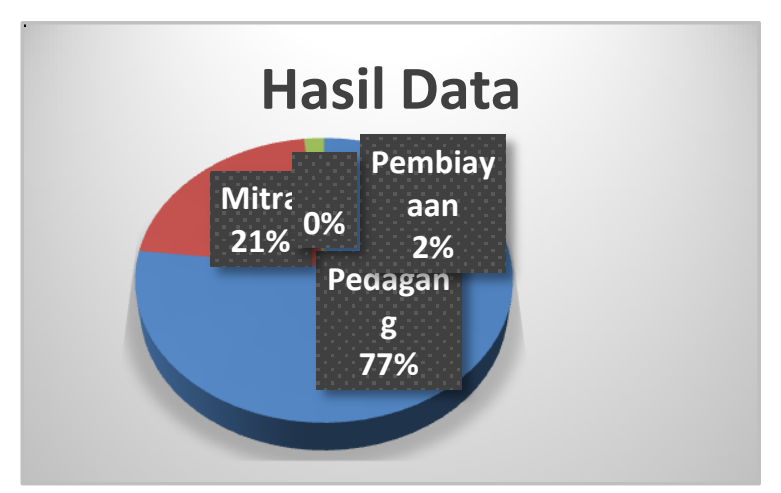


Hasil dari gambar diatas dapat diketahui dari 1800 pedagang (77\%) yang sudah tergabung menjadi mitra BMT Al-Falah ada 500 pedagang $(21 \%)$ menyatakan bahwa akses keuangan dari segi penyimpanan uang sudah baik. Namun hanya terdapat 44 pedagang (2\%) yang melakukan pembiayaan BMT Al-Falah, menyatakan bahwa akses dari segi pembiayaan modal pedagang masih kurang.

\section{Uji Korelasi Rank Spearman}

Korelasi rank spearman digunakan untuk mencari hubungan atau untuk menguji signifikasi hipotesis asosiatif bila masingmasing variabel dihubungkan berbentuk ordinal. Bahwa uji korelasi rank spearman merupakan bagian dari statistik non-parametik, oleh karena itu dalam analisis korelasi ini tidak diperlukan asumsi adanya hubungan yang linear (uji liniearitas) antara variabel penelitian. Jika data penelitian menggunakan skala likert maka jarak yang digunakan harus sama dan data penelitian tidak harus berdistribusi normal (Uji Normalitas).

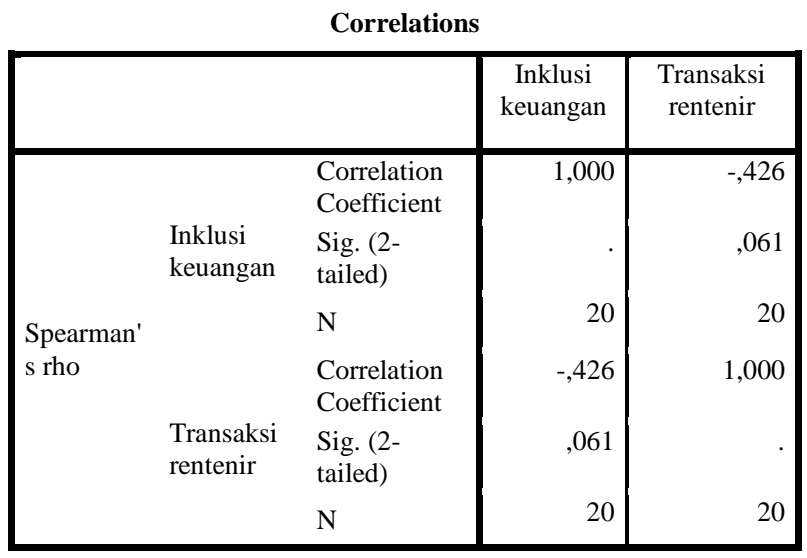

Berdasarkan hasil korelasi diatas didapatkan bahwa hubungan korelasi yang dimiliki sebesar -0,426 menandakan bahwa korelasi antara Program Inklusi Keuangan BMT Al-Falah Terhadap Transaksi Rentenir memiliki korelasi sedang. Tanda negatif mengartikan bahwa Program Inklusi Keuangan BMT Al-Falah meningkat maka Transaksi Rentenir akan menurun. Sedangkan dilihat dari nilai signifikasi 0,061 maka menyatakan bahwa hubungan korelasi antara Program Inklusi Keuangan BMT Al-Falah Terhadap Transaksi Renenir tidak signifikasi.

\section{Strategi-strategi BMT Al-Falah meminimalisir terhadap transaksi rentenir pada pedagang di Pasar Sumber}

Berdasarkan hasil wawancara dengan Bapak Karmu sebagai Bagian pemasaran didapatkan hasilnya bahwa kebanyakannya pengusaha menengah ke bawah tentu kita tahu hal yang menjadi masalah dikalangan mereka semua adalah kesulitan modal dan kemapuan mengakses keuangan pada lembaga keuangan. Kesulitan inilah yang memaksa para pedagang ini kebiasaan menggunakan jasa keuangan lewat rentenir alias meminjam uang. Karena para pedagang sudah terbiasa untuk meminjam lewat rentenir.

Maka dibutuhkan strategi-strategi agar BMT Al-Falah atau lembaga keuangan mikro syariah ini mampu masuk dalam lingkup kegiatan ekonomi usaha menengah kebawah ini. Strategi diantaranya adalah:

1. Melalui pendekatan oleh pihak BMT AlFalah biasanya bagian pemasaran menjelaskan singkat tentang produk, penjelasan dibuat semenarik mungkin agar para pedagang tertarik.

2. Memberikan pelayanan yang ramah sehingga para pedagang betah untuk bertanya mengenai produk-produk dan transaksi yang ada di BMT Al-Falah

3. Adanya kemudahan dalam bertransaksi karena pedagang dalam bertranskas dengan rentenir sudah terbiasa dengan transaksi yang sangat mudah

4. Memberikan fasilitas yaitu berupa jemput bola para pihak BMT Al-Falah terjun langsung ke lapangan untuk melakukan transaksi biasnaya, apabila pedagang yang ingin menabung dan mengambil uang.

5. Syarat dalam pengajuan pinjaman biasanya dipermudah. 
Dengan strategi-strategi diatas inilah yang mampu dilakukan BMT Al-Falah dalam menarik minat para pedagang dan menjauhakn diri dari para rentenir tersebut. Dengan startegi diatas dapat mengurangi para pedangang yang sudah terbiasa menggunakan jasa keuangan dari rentenir.

Dasarnya kebutuhan masyarakat terhadap kebutuhan bantun permodalan yang disalurkan oleh lembaga-lembaga keuangan seperti bank, belum bisa terjangkau bagi pelaku usaha menengah ke bawah yang notabene hanya mempunyai modal terbatas dan relatif kecil. Para pelaku usaha menengah bawah juga kadang sulit mengakses keuangan pada lembaga keuangan seperti bank, karena tidak begitu memahami teknisnya.

Inilah yang menyebabkan munculnya jasa-jasa keuangan yang bermunculan di masyarakat yaitu rentenir, meminjamminjamkan uang kepada pedagang meskipun kelihatanya tidak apa-apa tapi setiap kita melakukan pinjaman tidak membayar bunganya akan terus berntambah. Para pedagang terbiasa meminjam kepada para rentenir karena mudah dan cepat. Mereka lebih nyaman meminjam ke rentenir karena sudah banyak pedagang yang biasa meminjam.

Mulailah pemerintah mengadakan suatu program yang dinamakan program financial inclusion. Biasanya program ini dibuat untuk para usaha menengan kebawah. Dalam program ini BMT menjadi salah satu contoh lembaga yang dijadikan sebagai program tersebut. BMT sebagai lembaga keuangan mikro syariah ini mampu memberikan solusi dan pemahaman kepada para pedagang.

Bagi para pedagang selama memudahkan mereka pasti berminat menjadi mitra BMT. Apalagi dengan fasilitas "jemput bola" yang dilakukan oleh BMT semakin memudahkan dalam transaksi keuangan seperti menabung dan meminjam. BMT nyatanya cukup bersaing dengan penyedia jasa keuangan lainnya, karena fasilitasnya itu. Pelayanan yang mudah sehingga para pedagang mau untuk menjadi mitra BMT.

Berdasarkan hasil responden mengenai pelaksanaan program inklusi keuangan BMT Al-Falah menyatakan setuju sebesar $52 \%$ dan dilihat dari datanya sebanyak 500 pedagang yang sudah menjadi mitra BMT Al-Falah dilihat dari segi akses menyimpan uang sudah cukup baik dibandingkan akses pembiayaan modal. Berdasarkan Uji instrumen yaitu Uji validitas dan reabilitas dari 15 pertanyaan semuanya dikatakan valid dan reliabel.

Sedangakan hasil uji teknik analisis data menggunakan Uji Korelasi Rank Spearman yang menyatakan bahwa Pengaruh Program Inklusi Keuangan BMT Al-Falah mempunya korelasi yang sedang terhadap Transaksi Rentenir. Dan tanda negatif menyatakan apabila Progam Inklusi Keuangan BMT AlFalah meningkat ini mempengaruhi Transaksi Rentenir menjadi menurun. Sedangkan dilihat dari taraf sinifikasinya sebes 0,061 menyatakan bahwa tidak adah yang signifikan antara Pengaruh Program Inklusi Keuangan BMT AlFalah terhadap Transaksi Rentenir Pada Pedagang di Pasar Sumber.

\section{Penutup}

Masalah utama pedagang adalah modal, para pedagang tidak mampu mengakses keuangan pada lembaga keuangan seperti Bank, Koperasi, atau BMT. Mereka lebih suka menggunakan jasa rentenir walaupun menyengsarakan. Pemerintah memunculkan adanya Program Financial Inclusion yang diperuntukan pengusaha menengah kebawah. Dalam Program Financial Inclsuion ini BMT menjadi lembaga yang dijadikan sebagai program yang memberikan solusi pedagang untuk mengakese keuangan dalam hal ini modal. Pelaksanaan Program Financial Inclusion BMT Al-Falah dilihat dari segi akses keuangan untuk menabung cukup baik dibandingkan dari segi pengajuan pembiayaan.

Jawaban respoden mengenai pelaksanaan program inklusi keuangan BMT Al-Falah 
mengatakan setuju sebanyak 52\%. Diketahui dari 1800 pedagang (77\%) yang sudah tergabung menjadi mitra BMT Al-Falah ada 500 pedagang $(21 \%)$ menyatakan bahwa akses keuangan dari segi penyimpanan uang sudah baik. Namun hanya terdapat 44 pedagang $(2 \%)$ yang melakukan pembiayaan BMT Al-Falah, menyatakan bahwa akses dari segi pembiayaan modal pedagang masih kurang.

Sedangkan hasil, menggunakan Uji korelasi rank spearman sebesar $-0,426$ menandakan bahwa korelasi antara Program Inklusi Keuangan BMT Al-Falah Terhadap Transaksi Rentenir memiliki korelasi sedang. Tanda negatif mengartikan bahwa Program Inklusi Keuangan BMT Al-Falah meningkat maka Transaksi Rentenir akan menurun. Menunjukan bahwa adanya Pengaruh Program Financial Inclusion Terhadap Praktik Rentenir. Strategi-strategi yang dilakukan Pihak BMT Al-Falah dalam meminimalisir praktik rentenir sebagai berikut:

1. Memberikan Fasilitas "jemput bola" Pihak BMT terjun Langsung bertemu pedagang

2. Melalui pendekatan oleh pihak BMT AlFalah kepada pedagang

3. Memberikan pelayanan yang ramah dan kemudahan dalam bertransaski

\section{Daftar Pustaka}

Andri, Soemitra. Bank dan Lembaga Keuangan Syariah. Jakarta: Kencana, 2012

Anggraeni Dwi,F,dkk. "Pengembangan UMKM Melalui Fasilitas Pihak Eksternal dan Potensi Internal". Jurnal Administrasi 1, no. 6 (2011)

Antonion, Syafi'i. Bank Syariah Dan Teori Ke Praktik. Jakarta: Gema Insani Press, 2001

Ayogi Dwi, Kurnia Tuti. "Optimalisasi Peran BMT dalam Upaya Penghapusan Praktik Rentenir'Jurnal Syarikah 1,no.1 (2010)
Aziz ,Abdul dan Ulfah Mariyah, S.EI Kapita Selekta Ekonomi Islam Kontemporer. Bandung: Alfabeta, 2010.

Azwar, Saifuddin. Metode Penelitian. Yogyakarta : Pustaka Pelajar Offset, 2011

Azzam ,Abdul Aziz Muhammad. Fiqih Muamalat. Jakarta: Amzah ,2010

Buku Saku Keuangan Inklusif. Departemen Pengembangan Akses Keuangan dan UMKM Bank Indonesia, 2014

Chuzaimah Batubara, dkk. "BMT VERSUS DALAM PEMBERDAYAAN EKONOMI MASYARAKAT Studi Kasus di Kecamatan Percut Sei, Deli Serdang Sumatera Utara." Jurnal Ekonomi (2010)

Denizar, Abdurahman. "Linkage Program Bank Syariah Dengan BMT: Tinjauan Kritis Bagi Pengembangan Sistem Keuangan Yang Lebih Kaffah" Jurnal Ekonomi Syariah2, no.10 (Oktober, 2015)

Dewi Sri Yusuf. "Peran Strategi Baitul Maal Wal Tamwil (BMT) Dalam Peningkatkan Ekonomi Rakyat" Jurnal Al Mizan, 10 no.1 ,(Juni 2014)

Dimyauddin, Djuwaini. Pengantar Fiqih Muamalah. Yogyakarta: Pustaka Pelajar, 2004

Fitriastuti Triani, Dhina Mustika. S, Ike Purnamasari. "Impelemntasi Keuangan Inklusif Bagi MasyarakatPerbatasan (Studi Kasua Pada Kutai Timur, Kabupaten Kertanegara dan Kota Samarinda, KalimantanTimur, Indonesia)". Jurnal Ekonomi. Universitas Mulawarman, (2015)

Hasan, Iqbal. Anlisis Data Penelitian dengan Statistic. Jakarta: Bumi Aksara ,2004

Huda, Nurul dan Aliyadin, Acham. Keuangan Publik Islam Pendekatan Teoritis dan Sejarah. Jakarta: Kencana Prenada media Group ,2012

Huda, Nurul dan Heykal. Lembaga Keuangan Islam Tinjauan Teoritisdan Praktis. 
Jakarta: Kencana Prenada Media Group ,2010

Ibnu Mujar Syarif. "Konsep Riba Dalam AlQuran Dan Literatur Fiqih".

Aliqhtishad, 2 no.2 (Juli 2011)

Insan Deni Kamil. "Pengaruh Rentenir Terhadap Kesejahteraan Pedagang PasarTradisional Studi Pasar Legi Bugisan Jogjakarta". Universitas Sunan Kalijaga, (2015)

Juliansyah, Noor. Metodologi Penelitian.Jakarta: Kencana Prenada Media Group, 2013

Khudzaifah Dimyanti."TesisProfil Pelepas Praktek Uang Rentenir". Universitas Diponogoro ,(1997)

Kuncoro, Mudrajad. Metode Riset Untuk Bisnis \& Ekonomi, Edisi Keempat. Jakarta: Erlangga,2013

Made Sanjaya, Nursechafia. Inklusi Keuangan dan pertumbuhan inklusif analisis antar provinsi Indonesia- www.Bi.go.id (diakses pada tanggal 6 Februari pukul 14.52)

Manan, Abdul. Hukum Ekonomi Syariah dalam Perspektif Kewenangan dan Peradilan Agama. Jakarta: Kencana Prenanda. Media Group ,2012

Masitoh Eva Z. "Peran Baitul Maal Wal Tamwil Dalam Meningkatkan Prduktivitas Usaha Kecil Di Desa Cuplik Sukaharjo." Skripsi Universitas Sebelas Maret, (2009)

Muhamad. Lembaga Ekonomi Syariah. Yogyakarta: Graha Ilmu ,2007

Muhammad. Lembaga Keuangan Mikro Syariah. Yogyakarta: Graha Ilmu ,2009

Mulyaningrum. "Baitul Maal Wal Tamwil Peluang Dan Tantangan Dalam Pengembangan Lembaga Keuangan Mikro." Bakrie Scool Of Management, (2009)

Narbuko, Cholid dan Achamdi, Abu. Metodologi Penelitian. Jakarta: PT.Bumi Aksara, 2007
Nugraha, Heru. Uang, Rentenir dan Hutang Piutang di Jawa. Yogyakarta: Pustaka Pelajar ,2001

Nurjaman Jajang. "Peranan BMT Al-Fath IKMI Ciputat Dalam Mengatasi DampakNegatif Praktek Rentenir". Universitas Syarif Hidayatullah ,(2012)

Ridwan, Ahmad Hasan. BMT Bank Islam sebagai Instrumen Lembaga Keuangan

Rozalinda. "Peran BMT Taqwa Muhamdiyya Dalam Memberikan Masyarakat Dari Rentenir Di Kota Padang”. IAIN Imam Bonjol Padang, 7 no.2 (Desember 2013)

Sahrani, Sohari. dan Ruf'ah Abdullah,M.M. Fikih Muamalah. Bogor: Ghalia Indonesia, 2011

Setiawan Arief. "Peran BMT Dalam Meningkatkan Kinerja Mitra Binaanya (Studi Kasus Pada BMT Al-Ikhlas". Iain Syekh Nurjati Cirebon (2012)

Setyani Irmawati, Delu Damelia, dan Dita Wahyu Puspita. "Model Inklusi Keuanganpada UMKM berbasis Pedesaan”. Jurnal Ekonomi dan Politik Universitas Negeri Semarang. 6, no.2 ,(2013)

Sugiono. Statistik Untuk Penelitian. Bandung: Alfabeta, 2005

Suharsaputra Uhar .Metodologi Penelitian Kuantitatif, Kualitatif dan Tindakan. Bandung: Refika Aditama, 2012

Syariah. Bandung: Pustaka Bani Quraisy, 2004.

Vetihzal, Rivai dan Arifin, Arviyan. Islamic Banking .Jakarta: Bumi Aksara, 2010

Wahid, Nusron. Keuangan Inklusif Membongkar Hegemon Keuangan. Jakarta: Gramedia, 2014

Wardi Ahmad Muslich. Fiqih Muamalat. Jakarta: Amzah, 2013

Wijaya, Raried. Perkreditan, Bank dan

Lembaga-Lembaga Keuangan. Yogyakarta:

BPFE, 1991. 